\title{
Nearctic walnut leafminers invade Europe: first Coptodisca lucifluella (Clemens, 1860) and now Coptodisca juglandiella (Chambers, 1874) (Lepidoptera, Heliozelidae)
}

\author{
Attila Takács ${ }^{1}$, Csaba SzabóKY ${ }^{2}$, Balázs Tóth ${ }^{3}$, Miklós Bozsó ${ }^{4}$, \\ JÁnOs KutaS ${ }^{5}$, SzILÁrd MolnáR ${ }^{6}$, IGNÁC RICHTER ${ }^{7}$ \\ 1 Jászivány utca 64, H1172 Budapest, Hungary; molyirto@gmail.com \\ 2 Bécsi út 88,H1034 Budapest, Hungary; bothv@t-online.hu \\ 3 Baross utca 13,. H1088 Budapest, Hungary; toth.balazs@nhmus.hu \\ 4 Budaörsi út 141-145, H1118 Budapest Hungary; mikitv.bozs@gmail.com \\ 5 Kinizsi u.81.H8900 Zalaegerszeg,Hungary; kutas.janos@zala.gov.hu \\ 6 Sütö utca 20, H8000 Székesfehérvár, Hungary; eketalp@gmail.com \\ 7 Malá Čausa 289,SK97101 Slovakia, ignac.richter@gmail.com \\ http://zoobank.org/78CAD5A9-0D61-4024-8641-1FD15C2C29CA
}

Received 31 July 2019; accepted 21 February 2020; published: 14 April 2020

Subject Editor: Erik J. van Nieukerken.

\begin{abstract}
The Nearctic leafminer of black walnut Coptodisca juglandiella (Chambers, 1874) was found in Hungary and reported as new for Europe. Larvae were found in leafmines on black walnut (Juglans nigra (L.)), white walnut (J. cinerea (L.)) and Arizona walnut (J. major (Torr.)); the latter two Juglans species are new host plant records for C. juglandiella. Mines of Coptodisca lucifluella (Clemens, 1860), another Nearctic invader, were found on leaves of bitternut hickory (Carya cordiformis (Wangenh.) K.Koch) and Caucasian wingnut (Pterocarya fraxinifolia (Lam). Spach.) (a new hostplant record), in addition to common walnut (Juglans regia L.). Interestingly, C. lucifluella is thought to have performed a host plant shift after its introduction into Europe, whereas C. juglandiella apparently did not. Coptodisca juglandiella has three generations in Hungary. The autumn generations of both species produced many more mines than the spring generations. One hymenopteran parasitoid specimen was reared from $C$. juglandiella. Larvae, mines and adults of $C$. juglandiella and $C$. juglandiella can be easily distinguished, differences are presented and illustrated. The genitalia of $C$. juglandiella are described for the first time.
\end{abstract}

\section{Introduction}

The family Heliozelidae (superfamily Adeloidea) contains 125 described species, with the highest diversity in North America and Australia (Milla et al. 2017; van Nieukerken et al. 2018). The host plant spectrum of Heliozelidae is wide: it includes deciduous trees, shrubs, vines as well as herbs (van Nieukerken and Geertsema 2015; Milla et al. 2017). The larvae are leafminers which, when fully fed, prepare oval cases (shields) from the leaves, in which pupation occurs. In temperate regions, they overwinter in the prepupal stage (Nieukerken et al. 2012). Altogether 12 species of Heliozelidae were known to occur in Europe until now (van Nieukerken et al. 2018), three of them being aliens from North America: Antispila oinophylla van Nieukerken \& Wagner, 2012 (van Nieukerken et al. 2012), Coptodisca lucifluella (Clemens, 1860) (Bernardo et al. 2011b) and C. splendoriferella (Clemens, 1860) (Weiss 1918; Segerer et al. 2019). The first verified record of the $13^{\text {th }}$ species, $C$. juglandiella (Chambers, 1874), another alien from North America, is reported in this paper. 
The heliozelid genus Coptodisca Walsingham, 1895 is a New World taxon which includes 18 described species of tiny leafminer moths which feed on a wide variety of host plants (Bernardo et al. 2015). In 2010, a Coptodisca was found in Campania and Lazio (Italy) (Bernardo et al. 2011a, 2011b). Mines were found on common walnut (Juglans regia L.) and on black walnut (J. nigra (L.)). Specimens from J. regia were DNA barcoded and their identity, corroborated by morphological studies, was shown to be Coptodisca lucifluella (Bernardo et al. 2015). In its native range in North America, C. lucifluella feeds on hickory species (Carya spp.), but is only known from walnut (Juglans spp.) in the introduced range in Italy (Bernardo et al. 2015). The biology of C. lucifluella was extensively documented by Bernardo et al. (2015). Specimens from J. nigra were not DNA barcoded. Coptodisca lucifluella was subsequently also recorded from Hungary in 2017 (Takács et al. 2017), and in 2019 it was found in Ukraine, on J. regia, close to the Hungarian border (Pályi et al. 2019). Different host plant preferences and infection rates were detected in Hungary: all examined J. nigra trees were infected while we did not find mines on several J. regia trees. Where $J$. nigra and J. regia co-occurred, the former species was more frequently attacked than the latter by Coptodisca larvae at a ratio of 15:1 (Takács et al. 2017). We therefore suspected that two Coptodisca species could be present. Here, we show that our suspicion was correct and that two Coptodisca species are present in Hungary: C. lucifluella, a leafminer on J. regia, and C. juglandiella, with most occurrences on J. nigra. This paper presents the first records of $C$. juglandiella in Europe.

\section{Material and methods}

\section{Field work, records and rearing}

Since the discovery of C. lucifluella in 2017 in Hungary, we have searched for leaf mines on Juglans regia and J. nigra trees in 263 localities throughout the country, as well as on one tree each of white walnut (J. cinerea (L.)) and Arizona walnut (J. major (Torr.)). Additional specimens of the latter two species were not located. A locality is either a municipality (usually a village) or a district of Budapest. Food plants were examined until the first sighting of each Coptodisca species in each locality.

Coordinates of localities were compiled into the ETRS89 reference grid of $10 \times 10 \mathrm{~km}$ squares. Mines with larvae were collected in August 2018 from J. nigra trees in the villages of Alcsútdoboz, Magyaralmás and Előszállás (all in Fejér county), J. regia trees in Cece and Székesfehérvár (Fejér county), from J. major in Alsószentiván (Fejér county, in 2019), from J. cinerea in Martonvásár (Fejér county), from bitternut hickory (Carya cordiformis (Wagenh.) K.Koch) in Budapest (2019), and from Caucasian wingnut (Pterocarya fraxinifolia (Lam.) Spach) also in Budapest, (2019). Mines found in 2018 were reared under natural conditions, each in a separate plastic vial, and hibernated outdoors. Mines collected in summer 2019 were kept at room temperature, with adults emerging within a week.

\section{Adult material examined}

Coptodisca juglandiella: 2 q: Fejér county, Alcsútdoboz, reared from Juglans nigra, collected: 15.viii.2018, emerged: 24.viii.2018, leg. Attila Takács, slide Nos TB1901f, TB1905f; 1 đ̊: Fejér county, Alcsútdoboz, collected: 10.vi.2019, emerged: 19.vi.2019, leg. Attila Takács, slide No. TB1904m; 1 specimen [abdomen and head lost]: Fejér county, Alcsútdoboz, collected: 10.vi.2019, emerged: 19.vi.2019, leg. Attila Takács; 1 †, 1 đ̊: Fejér county, Alsószentiván, Juglans major, collected: 28.vi.2019, emerged: 15.vii.2019, leg. Attila Takács, slide No. GP 29822 IgR, GP 29820 IgR; 1 đ̊: Fejér 
county, Alsószentiván, Juglans nigra, collected: 01.vi.2018, emerged: 23.vi.2018, leg. Attila Takács, slide No. GP 29763 IgR; 1 ๆ: Fejér county, Magyaralmás, Juglans nigra, collected: 13.viii.2018, emerged: 14.viii.2018, leg. Attila Takács, slide No. TB1903f; 1 đ̊: Somogy county, Öreglak, reared from Juglans nigra, collected: 19.viii.2018. emerged 27.viii.2018. (coll. Csaba Szabóky)

Coptodisca lucifluella: 1 q: Baranya county, Pécs, reared from Juglans regia, collected: 22.v.2018, emerged: 2.vi.2018, leg. Attila Takács, slide No. GP 29762 IgR; 3 đ̊, 1 q: Zala county, Zalaszentgrót, reared from Juglans regia, collected: 31.vii.2018, emerged: 10.viii.2018, leg. Attila Takács, slide Nos TB1902m, TB1906m, TB1907m, TB1908f.

Adults were either pinned with minuten pins $(n=8)$ or glued to card points $(n=2)$ or stored unmounted in a small transparent capsule $(n=4)$. All adults are deposited in the Hungarian Natural History Museum (HNHM), unless stated otherwise.

\section{Photography and genitalia preparation}

Preimaginal stages were photographed by Miklós Bozsó and Attila Takács with a Leica MZ 7.5 stereomicroscope (Leica Microsystems); images were adjusted by Leica Application Suite (Leica Microsystems). Wings were kept in $10 \% \mathrm{KOH}$ solution for two hours at room temperature. Isolated abdomens were boiled in $10 \% \mathrm{KOH}$ solution for three minutes. All structures were mounted in euparal to prepare permanent microscope slides. Wings were stained with eosin. Wing preparations were photographed with an Olympus DP70 photographic microscope. Images were adjusted with the software Adobe Photoshop CS6.

\section{Molecular analysis}

\section{DNA extraction}

A total of ten specimens were selected for molecular analyses (Table 1). Specimens were killed and stored in 70\% alcohol. The genomic DNA was isolated from two legs of adult specimens or from a piece of the larval body. DNA was isolated with Quick-DNATM Tissue/Insect Miniprep Kit (Zymo Research) according to the recommended protocol of the manufacturer.

\section{PCR amplification and sequencing}

Amplification of the 658 bp COI barcode region was performed with the primers LCO-1490 and HCO-2198 (Folmer et al. 1994). The PCR mixture contained $2 \mu$ of template DNA, $7.5 \mu 1$ of $2 \times$ HotStart Taq Plus Master Mix (HotStart Taq Plus Master Mix Kit, Qiagen), $0.5 \mu$ l of each primer $(10 \mu \mathrm{M})$ and double distilled water to a final volume of $15 \mu \mathrm{l}$. The amplification profile consisted of a preheating step of $5 \mathrm{~min}$ at $95{ }^{\circ} \mathrm{C}$ followed by 5 cycles of $95{ }^{\circ} \mathrm{C}$ for $40 \mathrm{~s}, 45^{\circ} \mathrm{C}$ for $1 \mathrm{~min}$ and $72{ }^{\circ} \mathrm{C}$ for $1 \mathrm{~min}$, and additional 40 cycles at $95{ }^{\circ} \mathrm{C}$ for $40 \mathrm{~s}, 51^{\circ} \mathrm{C}$ for $1 \mathrm{~min}$ and $72{ }^{\circ} \mathrm{C}$ for $1 \mathrm{~min}$ and a final extension at $72{ }^{\circ} \mathrm{C}$ for $10 \mathrm{~min}$. Reaction was performed in a PTC-100 DNA thermal cycler (MJ Research). Products of amplification were analysed in $2 \%$ agarose gel with addition of ethidium bromide and visualised under UV light. The PCR products were purified using the USB ExoSAP-IT PCR Product Clean-Up reagent (Affymetrix). Amplicons were sequenced bidirectionally using the BigDye Terminator Cycle Sequencing Kit (v3.1) (Applied Biosystems) on a MegaBase $^{\text {TM }} 1000$ Sequencing System (GE Healthcare). Specimens used in this study are listed in Table 1 along with GenBank accession numbers (MN103407-MN103411). Sequences were inspected and translated in translate tool of ExPASy Bioinformatics Resource Portal (Artimo et al. 2012) to verify that they were free of stop codons. 
Table 1. Coptodisca specimens from Hungary used for molecular analyses.

\begin{tabular}{|c|c|c|c|c|c|c|c|c|}
\hline Species & $\begin{array}{l}\text { Host } \\
\text { plant }\end{array}$ & Locality & $\begin{array}{c}\text { Longitude / } \\
\text { Latitude }\end{array}$ & $\begin{array}{c}\text { Date of } \\
\text { collection }\end{array}$ & $\begin{array}{c}\text { Date of } \\
\text { emergence }\end{array}$ & Collector & $\begin{array}{c}\text { NCBI } \\
\text { GenBank } \\
\text { code/BOLD } \\
\text { System } \\
\text { project code }\end{array}$ & Stage \\
\hline C. lucifluella & J. regia & Zalaszentgrót & $\begin{array}{c}46^{\circ} 56.55^{\prime} \mathrm{N} \\
17^{\circ} 04.9^{\prime} \mathrm{E}\end{array}$ & 31.vii.2018 & 10.viii.2018 & János Kutas & $\begin{array}{l}\text { MN103407/ } \\
\text { JUG001-19 }\end{array}$ & Adul \\
\hline \multirow[t]{2}{*}{ C. juglandiella } & J. nigra & Alcsútdoboz & $\begin{array}{c}47^{\circ} 25.27^{\prime} \mathrm{N} \\
18^{\circ} 35.28^{\prime} \mathrm{E}\end{array}$ & 12.viii.2018 & 24.viii.2018 & $\begin{array}{l}\text { Attila } \\
\text { Takács }\end{array}$ & $\begin{array}{l}\text { MN103410/ } \\
\text { JUG004-19 }\end{array}$ & Adult \\
\hline & J. nigra & Alcsútdoboz & $\begin{array}{c}47^{\circ} 25.27^{\prime} \mathrm{N} \\
18^{\circ} 35.28^{\prime} \mathrm{E}\end{array}$ & 12.viii.2018 & 24.viii.2018 & $\begin{array}{l}\text { Attila } \\
\text { Takács }\end{array}$ & $\begin{array}{l}\text { MN103410/ } \\
\text { JUG004-19 }\end{array}$ & Adult \\
\hline C. lucifluella & J. regia & Székesfehérvár & $\begin{array}{l}47^{\circ} 12.47^{\prime} \mathrm{N} \\
18^{\circ} 25.32^{\prime} \mathrm{E}\end{array}$ & 12.viii.2018 & 22.viii.2018 & $\begin{array}{l}\text { Attila } \\
\text { Takács }\end{array}$ & $\begin{array}{l}\text { MN103408/ } \\
\text { JUG002-19 }\end{array}$ & Adul \\
\hline \multirow[t]{2}{*}{ C. juglandiella } & J. nigra & Magyaralmás & $\begin{array}{c}47^{\circ} 17.68^{\prime} \mathrm{N} \\
18^{\circ} 19.78^{\prime} \mathrm{E}\end{array}$ & 27.vii.2018 & 14.viii.2018 & $\begin{array}{l}\text { Attila } \\
\text { Takács }\end{array}$ & $\begin{array}{l}\text { MN103410/ } \\
\text { JUG004-19 }\end{array}$ & Adul \\
\hline & J. nigra & Előszállás & $\begin{array}{l}46^{\circ} 49.72^{\prime} \mathrm{N} \\
18^{\circ} 49.53^{\prime} \mathrm{E}\end{array}$ & 22.vii.2018 & 04.viii.2018 & $\begin{array}{l}\text { Attila } \\
\text { Takács }\end{array}$ & $\begin{array}{l}\text { MN103411/ } \\
\text { JUG005-19 }\end{array}$ & Adul \\
\hline C. lucifluella & J. regia & Cece & $\begin{array}{c}46^{\circ} 45.98^{`} \mathrm{~N}, \\
18^{\circ} 38.32^{\prime} \mathrm{E}\end{array}$ & 12.viii.2018 & 04.viii.2018 & $\begin{array}{l}\text { Attila } \\
\text { Takács }\end{array}$ & $\begin{array}{c}\text { MN103409/ } \\
\text { JUG003-19 }\end{array}$ & Adult \\
\hline \multirow[t]{3}{*}{ C. juglandiella } & J. nigra & Előszállás & $\begin{array}{l}46^{\circ} 49.72^{\prime} \mathrm{N} \\
18^{\circ} 49.53^{\prime} \mathrm{E}\end{array}$ & 12.viii.2018 & 04.viii.2018 & $\begin{array}{l}\text { Attila } \\
\text { Takács }\end{array}$ & $\begin{array}{l}\text { MN103410/ } \\
\text { JUG004-19 }\end{array}$ & Adult \\
\hline & J. major & Alsószentiván & $\begin{array}{c}46^{\circ} 47.75^{\prime} \mathrm{N}, \\
18^{\circ} 43.97^{\prime} \mathrm{E}\end{array}$ & 05.vii.2019 & $\mathrm{n} / \mathrm{a}$ & $\begin{array}{l}\text { Attila } \\
\text { Takács }\end{array}$ & $\begin{array}{l}\text { MN103410/ } \\
\text { JUG004-19 }\end{array}$ & Larva \\
\hline & J. cinerea & Martonvásár & $\begin{array}{c}47^{\circ} 19.03^{\prime} \mathrm{N}, \\
18^{\circ} 46.75^{\prime} \mathrm{E}\end{array}$ & 23.ix.2019 & $\mathrm{n} / \mathrm{a}$ & $\begin{array}{l}\text { Mátyás } \\
\text { Papp }\end{array}$ & $\begin{array}{l}\text { MN103410/ } \\
\text { JUG004-19 }\end{array}$ & Larva \\
\hline
\end{tabular}

\section{Sequence analysis and phylogenetic reconstruction}

The forward and reverse sequences were assembled with Staden Package 2.0.0b9. Our purpose was to use as many $C$. lucifluella, $C$. juglandiella sequences suitable for aligning as possible for our analysis (we found eight additional available unique sequences for these species from NCBI GenBank and BOLD Systems) (Bernardo et al. 2015; van Nieukerken et al. 2012). The multiple sequence alignment was carried out by ClustalW (Larkin et al. 2007), with default parameters for all available corresponding gene sequences of $C$. lucifluella and $C$. juglandiella and with outgroup taxa (Antispila argentifera Braun, 1927). Distance analysis within examined taxa was obtained based on uncorrected p-distances using MEGA 7 (Kumar et al. 2016).

The most appropriate model of nucleotide substitution was determined with MEGA under the Bayesian Information Criterion (BIC). The Tamura 3 parameter (T92) model with gamma distribution (G) (Tamura and Nei 1993) was selected for our phylogenetic reconstruction. Phylogenetic trees were constructed with the Maximum Likelihood (ML) method implemented in MEGA, starting from a random Neighbor Joining tree, with the default initial rearrangement settings and five discrete gamma categories. To obtain an estimate of the support for each node, a bootstrap analysis using 1000 replicates was performed. Bootstrap support is given on appropriate clades in the ML tree.

\section{Results}

\section{Coptodisca juglandiella}

Identification. The original description of $C$. juglandiella contains little information about the habitus of the moth ("Except that it is perhaps a trifle smaller, I cannot distinguish this species in 

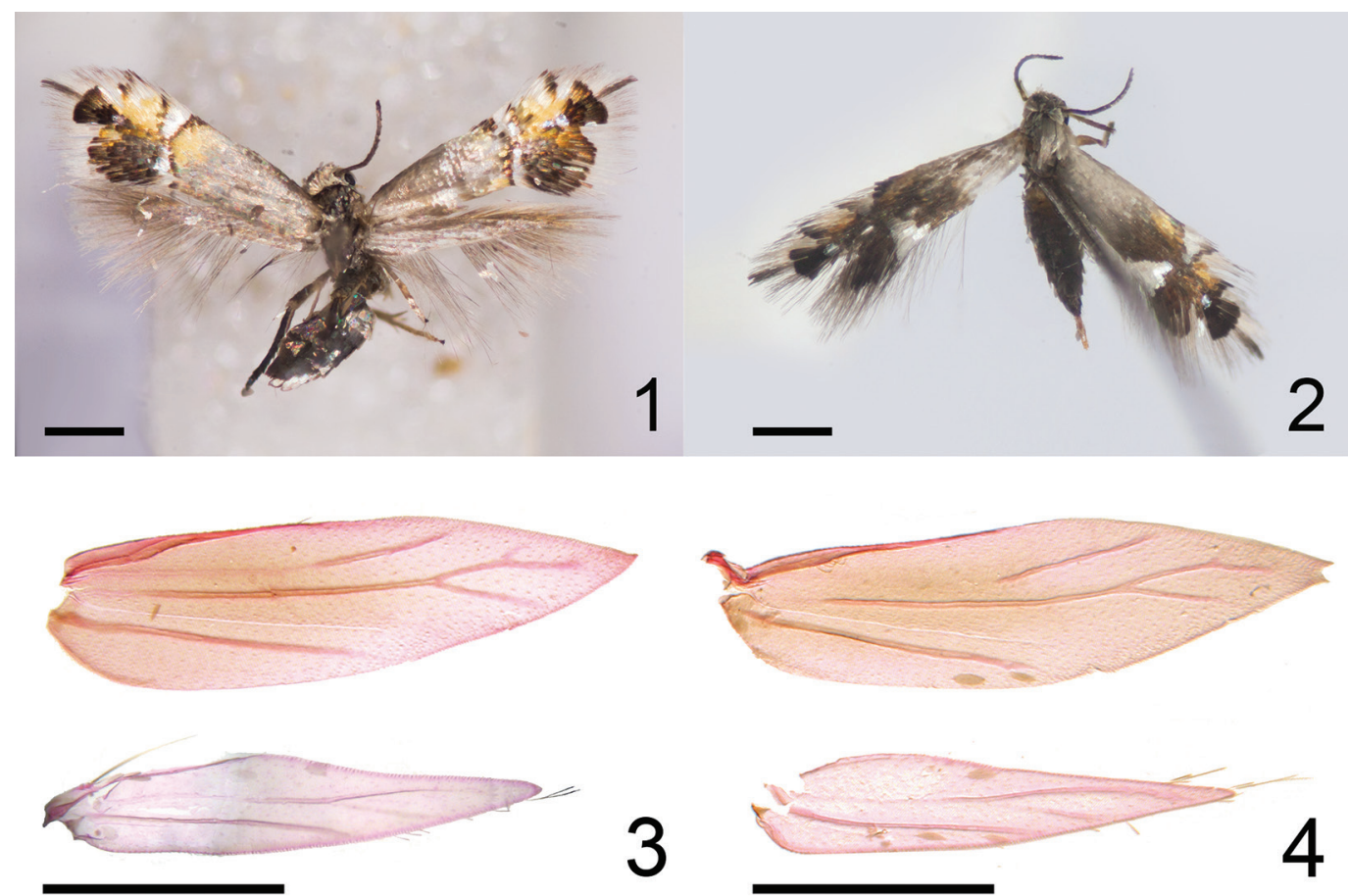

Figures 1-4. External morphology of Coptodisca species from Hungary. 1. Habitus of C. juglandiella male: Somogy county, Öreglak, reared from Juglans nigra (coll. Csaba Szabóky), 2. C. lucifluella female: Zala county, Zalaszentgrót, reared from Juglans regia (coll. HNHM). 3. Denuded right wings of $C$. juglandiella (TB1903f). 4. Denuded right wings of C. lucifluella (TB1902m). 1, 2: photo by Attila Takács, 3, 4: photo by Balázs Tóth. Scale bars: $0.5 \mathrm{~mm}$.

the imago from A. splendoriferella."); it deals rather with the mine, the case and host plant (Chambers 1874). On the contrary, Clemens (1860) gives a detailed description of the adult of $C$. lucifluella, but this is still not sufficient for identification. Bernardo et al. (2015) redescribed this species, designated and figured its lectotype and figured also an adult specimen of $C$. juglandiella and gave a brief diagnosis of the latter species. We did not have the opportunity to examine the type specimen(s) of C. juglandiella. According to Miller \& Hodges (1990) the majority of Chambers' types are deposited in the Museum of Comparative Zoology (Harvard University) but a significant number are located at the National Museum of Natural History (Smithsonian Institution, Washington $\mathrm{DC}=\mathrm{USNM}$ ) and there are also potential but probably untraceable type specimens at The Natural History Museum (London). This species is absent from the list of Miller and Hodges (1990). We consulted the type database of USNM without result (NMNH 2020), thus the type(s) may be lost. Hungarian specimens of the two species show the diagnostic differences underlined by Bernardo et al. (2015). There is an image of an intact C. juglandiella specimen on the homepage of the Moth Photographers Group (2019) which matches the diagnosis and image of Bernardo et al. (2015, suppl. material 3). Therefore, we are confident that the identifications of Hungarian specimens as C. lucifluella and C. juglandiella are correct.

Diagnosis. Adults of C. juglandiella (Fig. 1) are similar in external morphology to C. lucifluella (Fig. 2). However, the two species can be distinguished by wing pattern: the conspicuous black 
filling of $C$. lucifluella between the silvery grey basal area and the patch at dorsum is absent in C. juglandiella, in which the colour of this area is transitional from silvery grey (proximal edge) to yellow (distal edge). The silvery white tornal patch is narrower in $C$. juglandiella than in $C$. lucifluella. No differences in wing shape and venation were found between the two species (Figs 3,4 ). In the male genitalia, we found more sensilla of the pectinifer in C. juglandiella (Fig. 5a, b) than in C. lucifluella (Fig. 6a, b), while differences between the female genitalia of the two species were not observed.

The shape of the mines is different in the two species: in C. juglandiella mines are always round, $7 \mathrm{~mm}$ long and $5 \mathrm{~mm}$ wide on average (Fig. 11), mines of C. lucifluella are rather elongate and angular (Figs 9,10), average size $8 \mathrm{~mm} \times 5 \mathrm{~mm}$. The position of mines in leaflets is also different: mines of $C$. juglandiella are situated mostly close to the junction of the midrib and a lateral vein (Fig. 13), while the mines of C. lucifluella may occur throughout the leaflet (Fig. 12). Frass of the larva of $C$. juglandiella is hidden under a small area of the upperside parenchyma of the leaflet, preserved by the larva (Fig. 11), in contrast to the frass of C. lucifluella which is visible from both sides because it is dispersed in the mine and no cover is preserved (Fig. 10).

The body of the mature larva of $C$. juglandiella is off-white and its head, as well as the first two thoracic segments, are pale yellow (Fig. 15) while the larva of $C$. lucifluella is monochromatic rusty brown (Fig. 14).

We could not observe differences in the morphology of the cases or the pupae between the two species.

Morphology and recorded host plants. Adult. External characters (Figs 1, 3). Length of forewing 1.5-1.8 mm including fringe. Head silvery grey, rest of body dark silvery grey. Basal half of forewing silvery grey; two triangular patches present at distal thirds of costa and dorsum, these patches silvery white with black border at each side. Colour of the area between the silvery grey basal field and the patch at dorsum transitional from silvery grey to yellow in proximo-distal direction. Patch of dorsum narrow (Fig. 1).

Genitalia. In the male genitalia the pectinifer has six sensilla on right valva and seven sensilla on left valva (Fig. 5a, b). Phallus with two rows of anellar spines. Female genitalia with six oviscapt teeth: a pair of large ones anteriorly, posterior ones forming a broad, slightly indented apex (Fig. 6a). Corpus bursae ovoid, apparently without either scobinations or signum (Fig. 6b).

Mine. Coptodisca juglandiella prepares blotch mines (Fig. 11) visible on both sides of the leaf. Mines are always situated between lateral veins and never traverse them. The shape of mines is always round, $7 \mathrm{~mm}$ long and $5 \mathrm{~mm}$ wide on average. Mines usually start close to the junction of the midrib and a lateral vein. This species preserves a small area of the upperside palisade parenchyma of the leaflet and hides all of its frass under this cover.

Larva. Body off-white, head and first two thoracic segments pale yellow (Fig. 15).

Case. Prepared from an oval-shaped area of the leaflet, which is severed from the leaf by chewing the epidermis on both sides around this piece (Fig. 19). Then the oval plates are attached with silk along the edges, forming an oval-shaped shield, which is somewhat more elongate than the original leaf pieces, $2.9 \mathrm{~mm}$ long and $1.3 \mathrm{~mm}$ wide (Fig. 18).

Host plants. Coptodisca juglandiella is usually found on Juglans nigra in Hungary, but we also found it on J. major and J. cinerea (new hostplant records). 

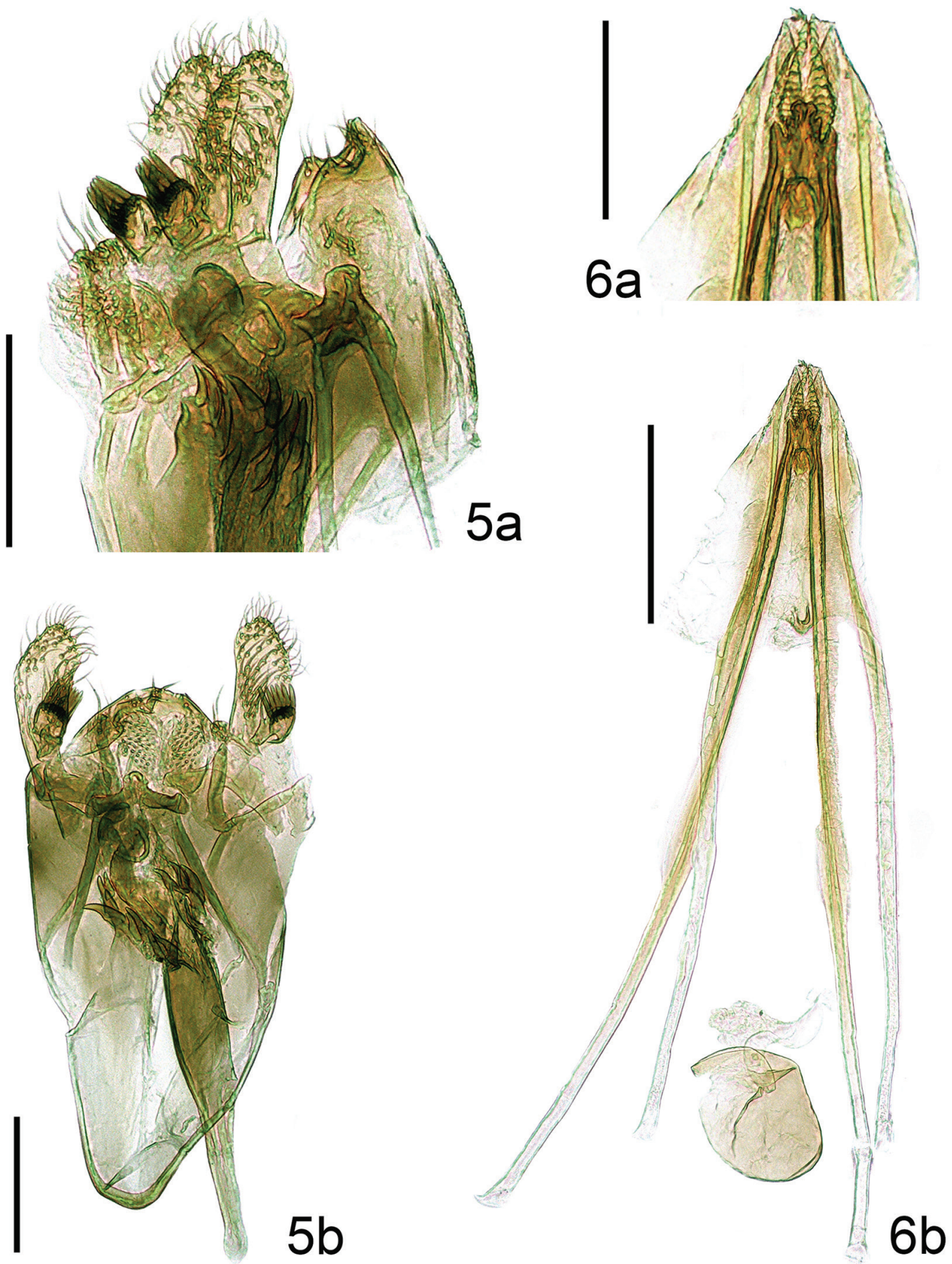

Figures 5, 6. Genitalia of Coptodisca juglandiella from Hungary, Alsószentiván, reared from Juglans nigra. 5a. Enlarged region of uncus, tegumen and valvae of male genitalia, lateral view (GP 29763 IgR). 5b. Ventral view of male genitalia (GP 29763 IgR). 6a. Enlarged region of oviscapt of female genitalia (GP $29822 \operatorname{IgR}$ ). 6b. Female genitalia (data as 6a). Photos by Ignác Richter. Scale bars: $0.1 \mathrm{~mm}(\mathbf{5 a}, \mathbf{5 b}, \mathbf{6 b}), 0.05 \mathrm{~mm}(\mathbf{6 a})$. 


\section{Coptodisca lucifluella}

Morphology and recorded host plants. Adult. External characters (Figs 2, 4). Length of forewing 1.5-1.8 mm including fringe. Head silvery grey, rest of body dark silvery grey. Basal half of forewing silvery grey, with two triangular patches present at distal thirds of costa and dorsum, white with black border on each side. Area between silvery grey basal field and tornal patch dark fuscous. Tornal patch broad, especially at base (Fig. 2).

Genitalia (Figs 7, 8). Male genitalia with five sensilla on pectinifers of both valvae $(\mathrm{n}=2$; right valva of an additional specimen lost, left valva with five teeth), elsewhere 5-7 sensilla (Bernardo et al. 2015, see fig. 7). Phallus with two rows of spines. Female genitalia with six oviscapt teeth, a pair of large ones anteriorly, posterior ones forming a wide, slightly indented apex (Fig. 8a). Corpus bursae rather pyriform, with neither scobinations nor signum (Fig. 8b).

Mine. This species prepares blotch mines visible on both sides of the leaf (Figs 9, 10). Mines are always situated between lateral veins and never traverse them. The shape of mines is rather elongate and angular (Fig. 10), average size $8 \mathrm{~mm} \times 5 \mathrm{~mm}$. Mines are positioned close to lateral veins, equally distributed from the midrib to the edge of the leaflet (Fig. 12). The frass of C. lucifluella is visible from both sides as it is dispersed in the mine (Fig. 9).

Larva. Mature larva $2.5 \mathrm{~mm}$ long, monochromatic rusty brown in colour (Fig. 14).

Case. Prepared from an oval-shaped area of the leaflet, severed from the leaf by chewing the epidermis on both sides around this piece (Fig. 19). Then the oval plates are attached with silk along the edges, forming an oval-shaped shield, which is somewhat more elongate than the original leaf pieces, $2.9 \mathrm{~mm}$ long and $1.3 \mathrm{~mm}$ wide (Fig. 18).

Pupa. Fresh pupa pale yellow, then becoming dark yellow, $2.7 \mathrm{~mm}$ long (Fig. 17).

Host plants. Host plants of C. lucifluella in Hungary are Juglans regia, Carya cordiformis and Pterocarya fraxinifolia (new hostplant record).

Remarks. Genitalia images prepared by us have a resolution too low for publication, but the above-mentioned characters are still observable. We illustrate here the genitalia with images kindly sent by Erik J. van Nieukerken (Fig. 7a, b; partly from Bernardo et al. 2015).

\section{Records of Coptodisca species in Hungary}

At least one Coptodisca species was present altogether in 227 localities, see Figs 20, 21. Coptodisca juglandiella was found in 31 localities while C. lucifluella was present in 216 localities. See Suppl. material 1 for the complete list of municipalities with data of sightings, including coordinates for the individual trees.

\section{Life cycle of Coptodisca species in Hungary}

Adults of the first generation emerge from mid-May to late May in both species. We found one mine per leaflet in the first generation, while there were three to eight mines present on each leaflet in the last generation, in both species.

Larvae consume the mesophyll of the leaf (Figs 9-11). The development time of larvae was eight to 18 days. Fully grown larvae made their case from the epidermis of the upper- and undersides of the leaflet (Fig. 19), then descended to the lower leaves of host plants by silken threads in the first half of June. They attached their case to those lower leaves or to the fruit. Pupation occurred in the case, and the pupal stage lasted for five to eight days. From June to October we 

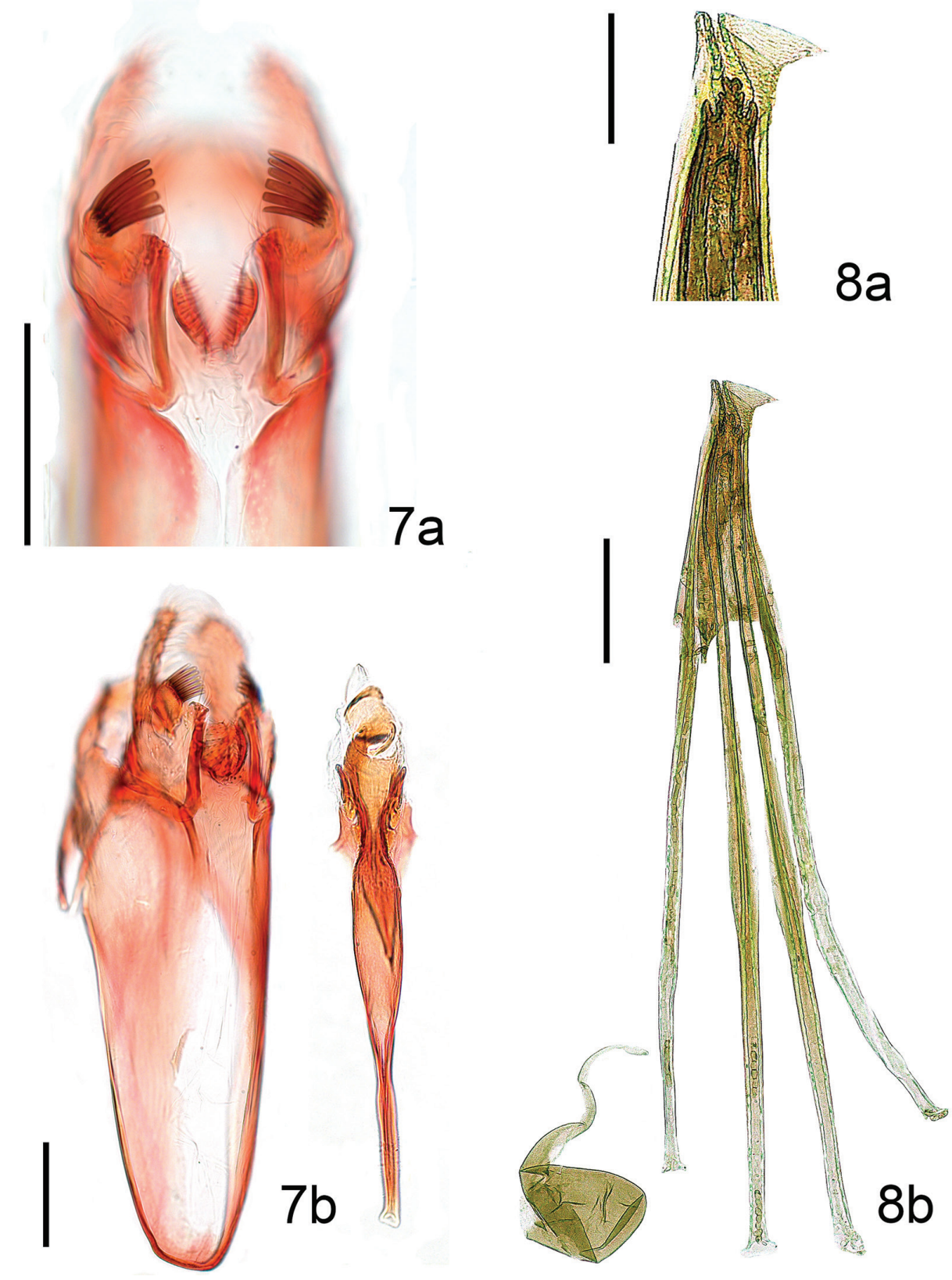

Figures 7, 8. Genitalia of Coptodisca lucifluella. 7a. Enlarged view of pectinifers of male genitalia, with five sensilla on left valva and six sensilla on right valva. Ventral view (from Bernardo et al. 2015, Italy, reared from $J$. regia, slide No. EvN 4462, coll. RMNH) 7b. Male genitalia with six sensilla on left valva and seven sensilla on right valva, semi-ventral view, phallus at right in ventral view (photos of male genitalia provided by Erik van Nieukerken, photograph of phallus from Bernardo et al. 2015, U.S.A., moth reared from Carya tomentosa, slide No. EvN 4458, coll. USNM). 8a. Enlarged region of oviscapt of female genitalia (Hungary, Pécs, 02.vi.2018, slide No. GP 29762 IgR). 8b. Female genitalia (data as 8a). 7a, 7b: photo by Erik van Nieukerken, 8a, 8b: photo by Ignác Richter. Scale bars: $0.1 \mathrm{~mm}$ (7a, 7b, 8b), 0.05 mm (8a). 


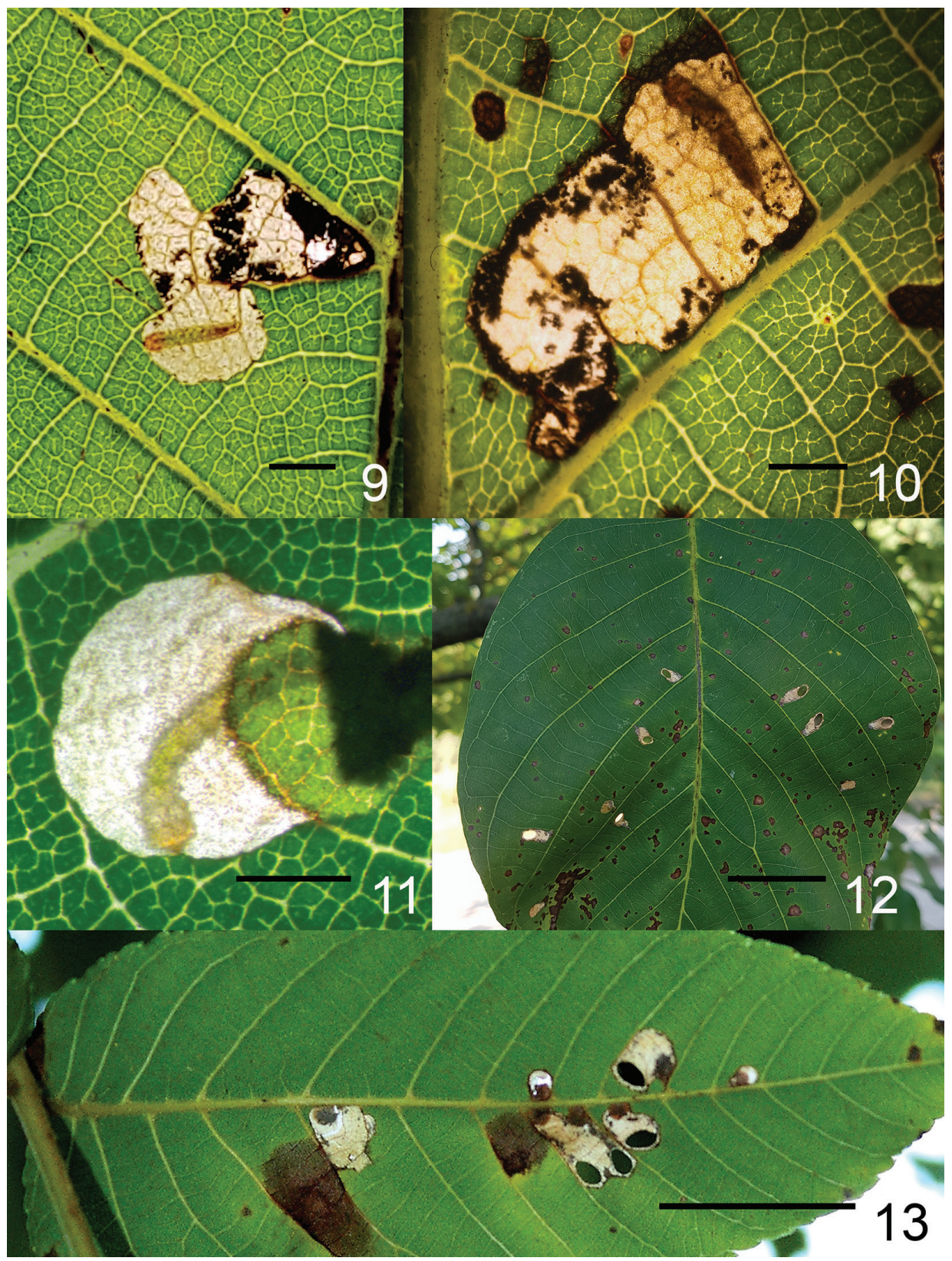

Figures 9-13. Blotch mines of Coptodisca species in Hungary. 9. Mine of. C. lucifluella with larva, frass dispersed. 10. Another mine of. C. lucifluella with larva, higher magnification than 9. Both mines on J. regia, Tornyiszentmiklós, 27.viii.2017. 11. Mine of $C$. juglandiella with larva, frass covered by a small area of the upper parenchyma. On J. nigra, Fejér county, Alcsútdoboz, 21.v.2018. 12. Vacated mines of C. lucifluella, scattered throughout the leaflet. On J. regia, Fejér county, Lovasberény, 14.x.2019. 13. Vacated mines of $C$. juglandiella, close to midrib. On J. nigra, Fejér county, Alcsútdoboz, 19.viii.2019. Photos by Miklós Bozsó. Scale bars: 2 mm (9-11), 20 mm (12, 13). 


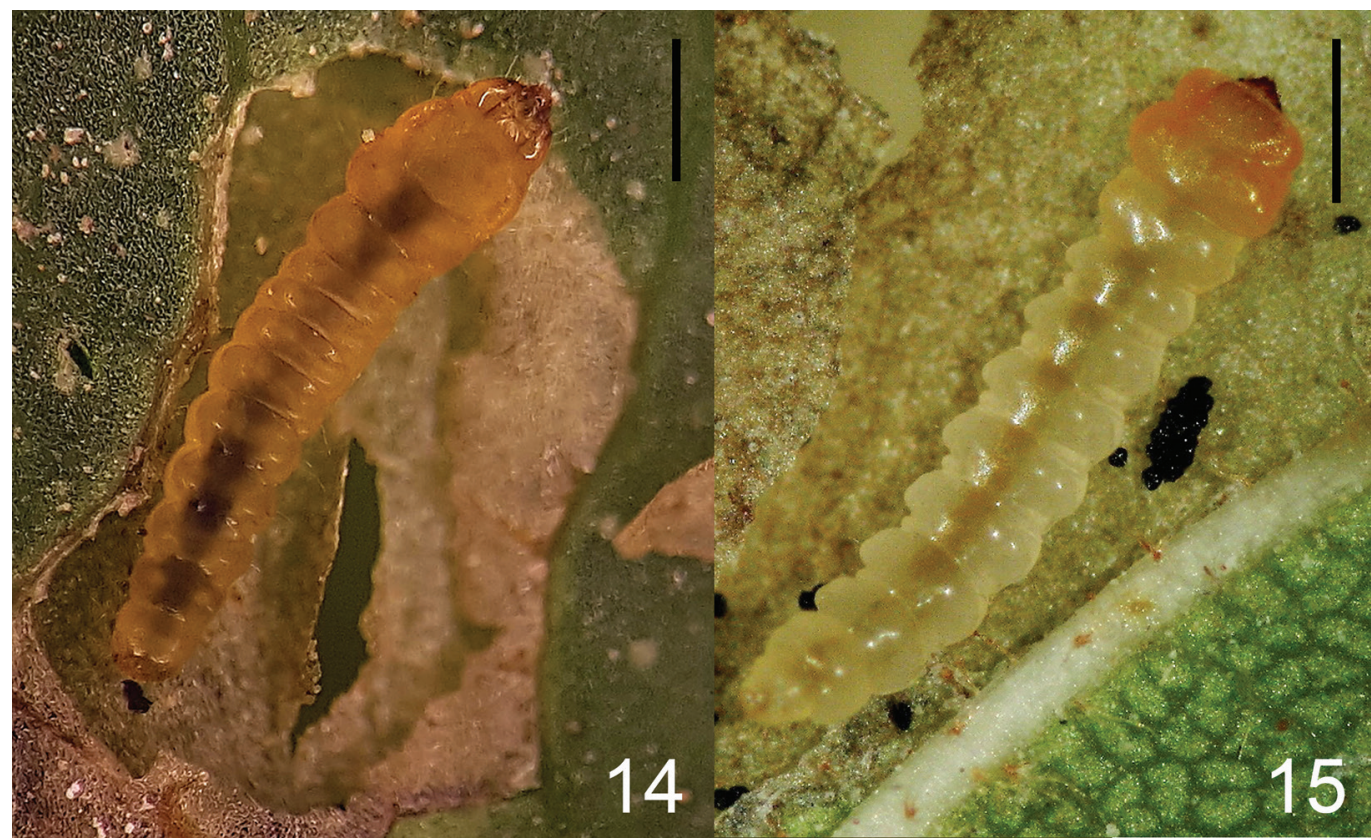

Figures 14, 15. Mature larvae of Coptodisca species from Hungary. 14. C. lucifluella, on J. regia, Fejér county, Lovasberény, 15.x.2019. 15. C. juglandiella, on J. nigra, Fejér county, Alcsútdoboz, 29.viii.2018. Photos by Attila Takács. Scale bars: $0.5 \mathrm{~mm}$.

continuously found active mines (living larvae). Larvae preparing for hibernation descended to twigs or the trunk of the host plant - or even to other nearby plants - by silken threads in September and October and attached their cases to those surfaces where overwintering occurred. Mortality of larvae was very high in this stage, and most larvae died in their mines. The causes of mortality were not studied. Successfully overwintered larvae pupated in late April or early May. Altogether 23 adults of $C$. lucifluella and 13 adults of $C$. juglandiella emerged.

\section{Molecular analysis}

The alignment of the COI counted 425 positions in the final dataset. Relationships among examined taxa and populations inferred from the analysed mtDNA region are shown in Fig. 22.

Based on results of our analysis, the intraspecific mean distance of the common clade of "lucifluella" populations was $0.9 \%$ (less than 4 basepairs). The "lucifluella" clade divided into two subclasses according to our data. Two Hungarian (Zalaszentgrót, Székesfehérvár) populations formed a common clade with other studied American, Canadian and Italian populations. The third Hungarian population (Cece) and one of the studied American population (KJ427015) probably formed a common clade with the same sequence based on our analysis.

In the case of $C$. juglandiella the examined seven specimens from five populations were characterised by two sequences. This was explained by the fact that six specimens - two specimens from Alcsútdoboz, one specimen from Magyaralmás, Előszállás, Alsószentiván and Martonvásár 


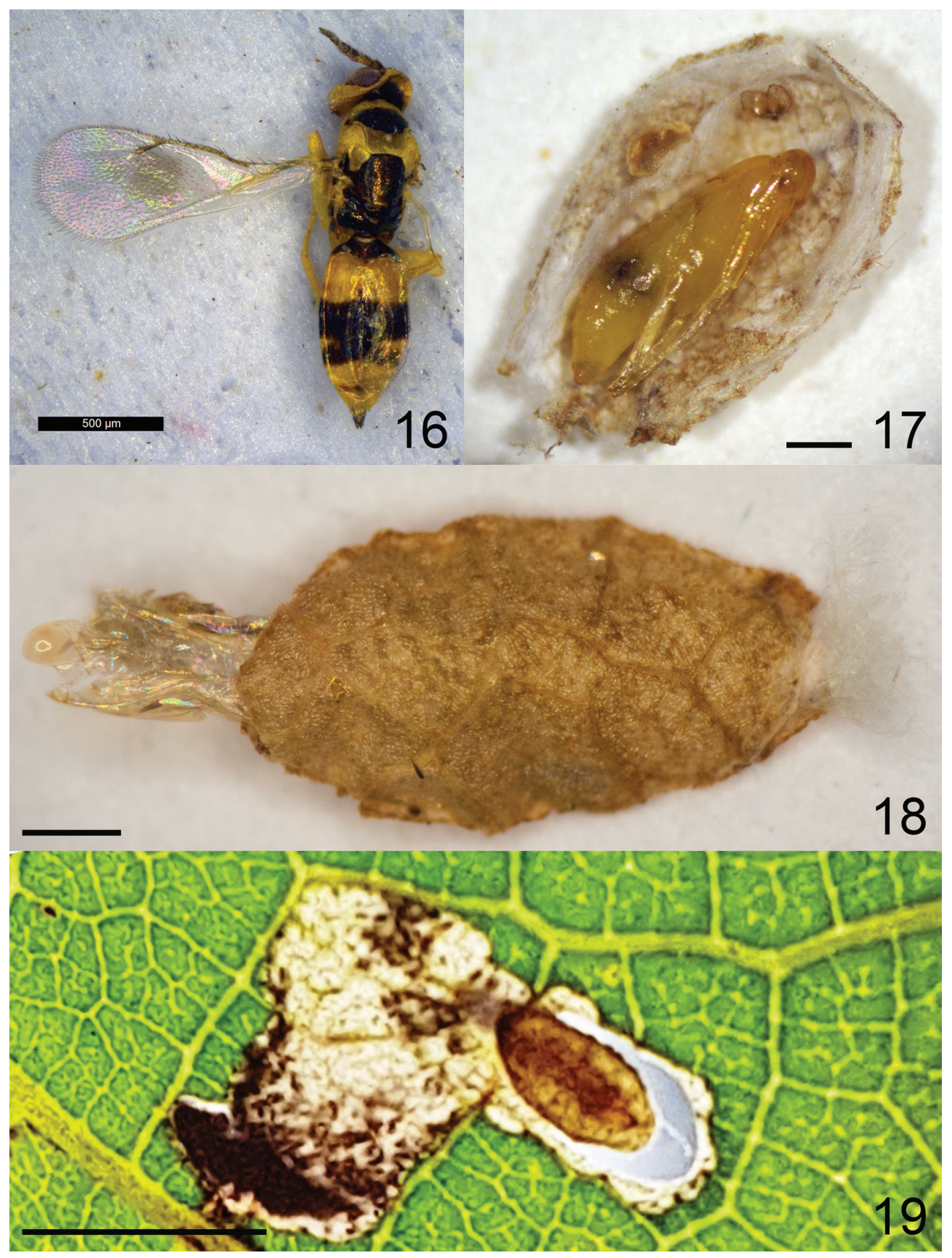

Figures 16-19. Parasitoid wasp, cases and pupae of Coptodisca species from Hungary. 16. Unidentified Closterocerus Westwood, 1833 species, female, reared from C. juglandiella. Alcsútdoboz, 22.vi.2018. 17. Pupa of C. lucifluella, in an opened case from J. regia, Zala county, Tornyiszentmiklós, 27.viii.2017. Photo by Miklós Bozsó. 18. Case with exuviae, C. juglandiella, from J. nigra, Fejér county, Alcsútdoboz, 29.viii.2019. 19. Case just finished, C. lucifluella, on J. regia, Zala county, Tornyiszentmiklós, 27.viii.2017. Photos by Attila Takács. Scale bars: $0.5 \mathrm{~mm}(\mathbf{1 6}-\mathbf{1 8}), 5 \mathrm{~mm}(\mathbf{1 9 )}$. 

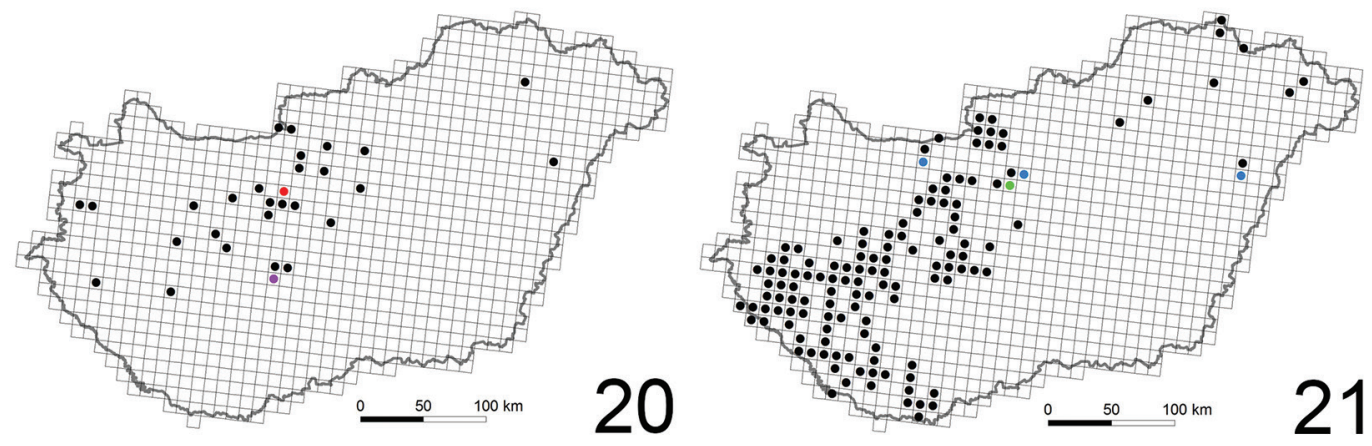

Figures 20, 21. Collecting sites of Coptodisca species in Hungary mapped on $10 \times 10 \mathrm{~km}$ squares. 20. C. juglandiella: black dot $=$ mines on Juglans nigra , red dot $=$ mines on J. cinerea, purple dot $=$ mines on J. major . 21. C. lucifluella: black dot $=$ mines on $J$. regia, green dot $=$ mines on Carya cordiformis, blue dot $=$ mines on Pterocarya fraxinifolia.

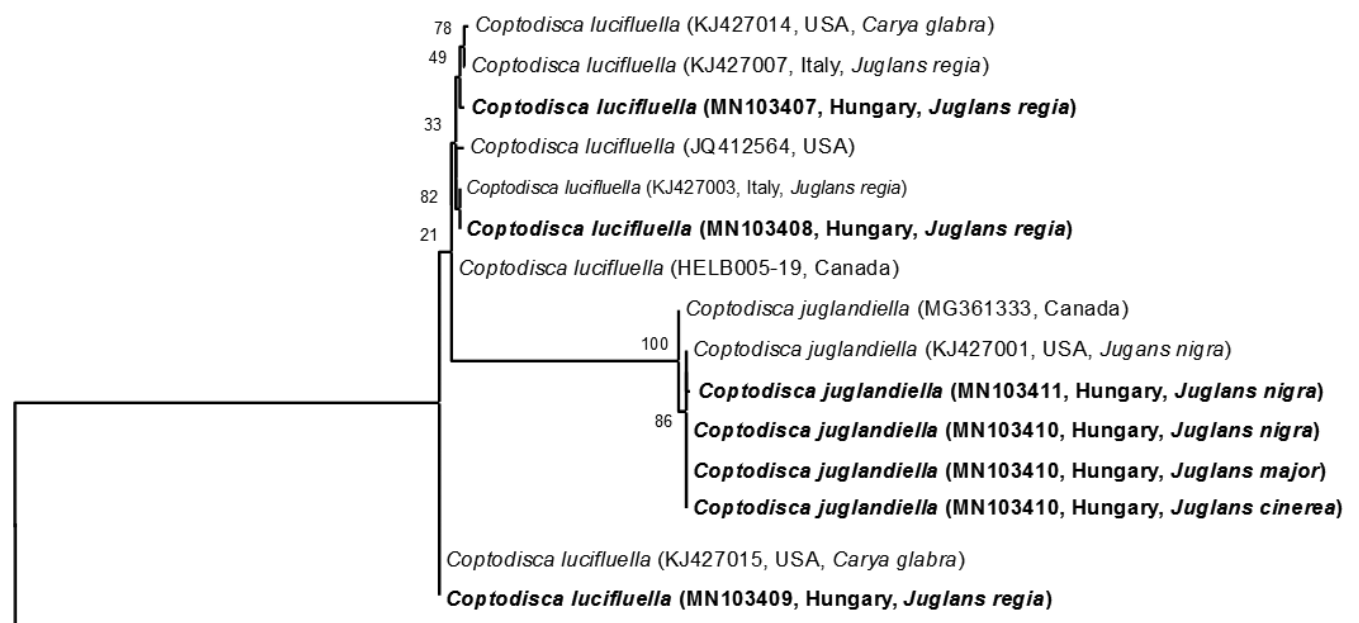

Antispila argentifera (MF118282)

Figure 22. Phylogenetic relationships of examined $C$. juglandiella and C. lucifluella populations. The best likelihood phylogenetic tree was inferred from the COI sequence ( $425 \mathrm{bp}$ ) alignment under the T92+G model. The percentage of replicate trees in which the associated taxa clustered together in the bootstrap test (1000 replicates) is shown next to the branches. Species name, GenBank or BOLD Accession number are listed for each taxon. Sequences of Hungarian Coptodisca populations are indicated in bold. The scale bars represent the number of substitutions per site.

- had the same sequence (MN103410). The intraspecific mean distance of the common clade of "juglandiella" populations was $0.3 \%$ (less than 2 basepairs). The interspecific mean distance between studied Coptodisca taxa was $8.5 \%$ (36 basepairs). 


\section{Parasitoids}

Altogether $40 \%$ of cases we found during field work had a round exit hole of a parasitoid insect. In rearing, only one female of an unidentified Closterocerus Westwood, 1833 (Hymenoptera: Eulophidae) (Fig. 16) emerged from a C. juglandiella case. Data of the specimen: Fejér county, Alcsútdoboz, emerged: 22.vi.2018., leg. Attila Takács (to be deposited in HNHM). We did not find additional parasitized larvae.

\section{Discussion}

Each newly introduced species should be examined with special regard to its tendency of invasiveness in order to explore any possible negative effects on indigenous ecosystems. We lack knowledge of the life cycles and natural enemies of the majority of alien species (Sundseth et al. 2019), and this is also true for $C$. juglandiella. Colonisation by an invasive species can be devastating and it can seriously reduce the populations of its host plant. In Hungary, the leaves of horse chestnut (Aesculus hippocastanum (L.)) trees fall already in mid-August due to combined effects of the mines of Cameraria ohridella Deschka et Dimić, 1986 and the induced fungal diseases (Tuba et al. 2012, pp. 96-97). This damage forces the tree to sprout, utilising its winter buds (which are also flower buds), hence degrading its condition. The resulting stress can lead to death of the tree.

In the genitalia of Coptodisca species we found some differences compared to the results of Bernardo et al. (2015). They found that in the male genitalia of $C$. lucifluella the pectinifer of the left valva contains one more sensillum than that of the right valva, but our two examined specimens have five sensilla in the pectinifer of each valva. Lafontaine (1974) included the number of pectinifer teeth in his description of C. matheri Lafontaine, 1974 but Opler (1971), in the diagnosis of $C$. powellella Opler, 1971 omitted it, and referred to the aedeagus (= phallus) bearing "the most obvious differences". He illustrated the genitalia of his new species together with those of C. quercicolella Braun, 1927; according to these line-drawings the number and shape of sensilla are different in these two species. In the female genitalia of our $C$. lucifluella specimen the number of oviscapt teeth are the same as in the specimens of Bernardo et al (2015). The differences we observed in the genitalia of $C$. lucifluella versus $C$. juglandiella are to be interpreted with reservation due to (1) the very low sample size and (2) the fact that a taxonomic revision on this group is still lacking.

The examination of DNA barcodes confirmed that there are two Coptodisca species feeding on Juglans trees in Hungary. Our phylogenetic analysis showed that the populations of the studied Coptodisca taxa did not form well-separated clades in all cases, some separation was only weakly supported. The Hungarian C. lucifluella populations clustered in a common clade with populations from Italy, Canada and the USA. This clade seems to be separated from its closely related sister clade which contains all studied C. juglandiella populations. In both species, we observed that the sequences of some Hungarian populations were identical to sequences of Italian or American specimens. These observations may be supporting the scenario of two recent introductions from the Nearctic.

Although C. lucifluella in Italy was also recorded from mines on J. nigra, no specimen was barcoded from that host plant (Bernardo et al. 2015), so the identity of that population needs to be re-examined. Coptodisca lucifluella is found on J. regia, C. cordiformis and P. fraxinifolia in Hungary while $C$. juglandiella feeds on J. major, J. nigra and J. cinerea. Juglans nigra was previously known as host plant for $C$. juglandiella (e.g. Bernardo et al. 2015; Eiseman 2019) while J. major and $J$. cinerea are new host plants for this species. 
Juglans species are not indigenous in Hungary. Juglans regia was introduced when Transdanubia was part of the Roman Empire as Pannonia. Juglans nigra appeared in botanical gardens in the $18^{\text {th }}$ century (Bencat 1982), but became widespread in the last 50 years, cultivated for its wood. Carya and Pterocarya species occur only as ornamental trees in Hungary, mainly in botanical gardens. We are not able to trace back when the Coptodisca species appeared in Hungary: at the time of discovery they were already widespread.

The native host plant of $C$. juglandiella in North America is J. nigra. As it simply found the same plant species in Hungary, it was able to spread rapidly. For C. lucifluella, the situation is different: individuals of its native host plant in Europe are very isolated and thus the moth could have limited chance of expansion without a host plant shift. Juglans regia, the main European host plant of $C$. lucifluella, is not indigenous in North America. Host plant shift was suggested by Bernardo et al. (2011) to explain the presence of C. lucifluella in Italy, however, we still do not have enough data to determine the time and place of that event.

At least three generations of C. juglandiella can develop per year in Hungary but, due to the continuous presence of active mines from June to October, the generations appear to overlap and it is difficult to establish their real number. We have shown that C. juglandiella and C. lucifluella have been present in Hungary for several years and occur now all over the country. While these species were extending their range, they remained undetected until recently. Kremer et al. (2008) listed 17 European countries where J. nigra is present, and C. juglandiella should be searched for in these states.

The parasitoid specimen belongs to a eulophid (Hymenoptera) genus that is distributed in the Holarctic and Australian Regions, with several species specialised on leafminers of various insect orders (Protasov et al. 2007).

Damage by Coptodisca larvae is not a subject of concern yet, but a constellation of unfavourable weather conditions and a large population explosion could cause deterioration of the condition of Juglans trees due to leaf surface loss.

\section{Acknowledgements}

We are indebted to Erik J. van Nieukerken for much help, numerous useful comments and corrections as well as providing images. We are grateful to Brigitta Barabási (Government Office of Fejér County), László Papp (ELTE Botanical Garden, Budapest), Mátyás Papp (Szent István University, Budapest), Ágnes Szénási (Szent István University, Gödöllő) and Dóra Vikár (Government Office of Pest County) for their kind help in field work. We are grateful to George Melika (National Food Chain Safety Office, Budapest) for determination of the parasitoid specimen. Our thanks are due to Antal Kristóf (Government Office of Fejér County) for preparing the maps. A Nota Lepidopterologica editor provided linguistic improvements to the text.

\section{References}

Artimo P, Jonnalagedda M, Arnold K, Baratin D, Csardi G, de Castro E, Duvaud S, Flegel V, Fortier A, Gasteiger E, Grosdidier A, Hernandez C, Ioannidis V, Kuznetsov D, Liechti R, Moretti S, Mostaguir K, Redaschi N, Rossier G, Xenarios I, Stockinger H (2012) ExPASy: SIB bioinformatics resource portal. Nucleic Acids Research, 40(W1): W597-W603. https://doi.org/10.1093/nar/gks400 
Bencat F (1982) Atlas of the distribution of exotic woody plant in Slovakia and zoning of their cultivation. Slovenska Akademia Vied, Arboretum Mlynany, Bratislava, 366 pp.

Bernardo U, Sasso R, Gebiola M, Viggiani G (2011a) Minatrice fogliare segnalata in Italia su noce. [Leafminer reported in Italy on walnut.] L'Informatore agrario 46: 64-65. [in Italian]

Bernardo U, Sasso R, Gebiola M, Viggiani G (2011b) First record of a walnut shield bearer Coptodisca (Lepidoptera: Heliozelidae) in Europe. Journal of Applied Entomology 136: 638-640. https://doi.org/10.1111/ j.1439-0418.2011.01693.x

Bernardo U, van Nieukerken EJ, Sasso R, Gebiola M, Gualtieri L, Viggiani G (2015) Characterization, distribution, biology and impact on Italian walnut orchards of the invasive North-American leafminer Coptodisca lucifluella (Lepidoptera: Heliozelidae). Bulletin of Entomological Research 105(2): 210-224. https:// doi.org/10.1017/S0007485314000947

Chambers VT (1874) Micro-Lepidoptera. The Canadian Entomologist 6: 149-153. https://doi.org/10.4039/ Ent6149-8

Clemens B (1860) Contributions to American Lepidopterology. No. 5. Proceedings of the Academy of Natural Sciences of Philadelphia 12: 203-221.

Eiseman C (2019) Leafminers of North America. E-book, self-published, 1999 pp.

Folmer O, Black M, Hoeh W, Lutz R, Vrijenhoek R (1994) DNA primers for amplification of mitochondrial cytochrome c oxidase subunit I from diverse metazoan invertebrates. Molecular Marine Biology and Biotechnology 3: 294-299.

Kremer D, Čavlović J, Božić M, Dubravac T (2008) Distribution and management of black walnut (Juglans nigra L.) in Croatia. Periodicum Biologorum 110 (4): 317-321. https://hrcak.srce.hr/file/56742

Kumar S, Stecher G, Tamura K (2016) MEGA7: Molecular Evolutionary Genetics Analysis version 7.0 for bigger datasets. Molecular Biology and Evolution 33(7): 1870-1874. https://doi.org/10.1093/molbev/msw054

Lafontaine JD (1974) A new species of Coptodisca (Heliozelidae) from Mississippi on Farkleberry (Vaccinium arboreum). Journal of the Lepidopterists' Society 28(2): 126-130.

Larkin MA, Blackshields G, Brown NP, Chenna R, Mcgettigan PA, Mcwilliam H, Valentin F, Wallace IM, Wilm A, Lopez R, Thompson JD, Gibson TJ, Higgins DG (2007) Clustal W and Clustal X version 2.0. Bioinformatics 23: 2947-2948. https://doi.org/10.1093/bioinformatics/btm404

Milla L, Nieukerken EJ van, Vijverberg R, Doorenweerd C, Wilcox SA, Halsey M, Young DA, Jones T, Kallies, A Hilton DJ (2017) A preliminary molecular phylogeny of shield-bearer moths (Lepidoptera: Adeloidea: Heliozelidae) highlights rich undescribed diversity. Molecular Phylogenetics and Evolution 120: 129-143. https://doi.org/10.1016/j.ympev.2017.12.004

Miller SE, Hodges RW (1990) Primary types of Microlepidoptera in the Museum of Comparative Zoology (with a discursion [sic!] on V. T. Chambers' work). Bulletin of the Museum of Comparative Zoology 152(2): 45-87.

Moth Photographers Group (2019) Coptodisca juglandiella. https:/mothphotographersgroup.msstate.edu/ species.php?phylo=210089 [Accessed 1 November 2019]

Nieukerken EJ van, Geertsema H (2015) A new leafminer on grapevine and Rhoicissus (Vitaceae) in South Africa within an expanded generic concept of Holocacista (Insecta, Lepidoptera, Heliozelidae). ZooKeys 507: 41-97. https://doi.org/10.3897/zookeys.507.9536

Nieukerken EJ van, Wagner DL, Baldessari M, Mazzon L, Angeli G, Girolami V, Duso C, Doorenweerd C (2012) Antispila oinophylla new species (Lepidoptera, Heliozelidae), a new North American grapevine leafminer invading Italian vineyards: taxonomy, DNA barcodes and life cycle. ZooKeys 170: 29-77. https://doi.org/10.3897/zookeys.170.2617

Nieukerken EJ van, Lees DC, Doorenweerd C, Koster S, Bryner R, Schreurs A, Timmermans MJTN, Sattler K (2018) Two European Cornus L. feeding leafmining moths, Antispila petryi Martini, 1899, sp. rev. and A. treitschkiella (Fischer von Röslerstamm, 1843) (Lepidoptera, Heliozelidae): an unjustified synonymy and overlooked range expansion. Nota Lepidopterologica 41(1): 39-86. https://doi.org/10.3897/nl.41.22264 
NMNH (2020) Search the Department of Entomology Collections. https://collections.nmnh.si.edu/search/ ento/ [Accessed 29 January 2020]

Opler PA (1971) Seven new lepidopterous leaf-miners associated with Quercus agrifolia (Heliozelidae, Gracillariidae). Journal of the Lepidopterists' Society 25(3): 194-211.

Pályi B, Takács A, Szabóky Cs (2019) Új diókártevő Kárpátalján. [New pest of walnut in Subcarpathia.] Kárpátaljai Vállalkozók Lapja 4(2): 16. [in Hungarian]

Protasov A, Blumberg D, Brand D, La Salle J, Mendel Z (2007) Biological control of the eucalyptus gall wasp Ophelimus maskelli (Ashmead): Taxonomy and biology of the parasitoid species Closterocerus chamaeleon (Girault), with information on its establishment in Israel. Biological Control 42: 196-206. https://doi. org/10.1016/j.biocontrol.2007.05.002

Segerer H, Gottschaldt KD, Grünewald T, Guggemoos T, Haslberger A (2019) Ergänzungen, Aktualisierungen und Korrekturen zur Checkliste der Schmetterlinge Bayerns (6. Beitrag) (Insecta: Lepidoptera). [Additions, updates and corrections to the checklist of butterflies in Bavaria (6 $6^{\text {th }}$ contribution) (Insecta: Lepidoptera).] Nachrichtenblatt der Bayerischen Entomologen 68(1/2): 47-52. [in German]

Sundseth K (2019) Invasive alien species of Union concern. Publications Office of the European Union, Luxembourg, $39 \mathrm{pp}$.

Takács A, Szabóky Cs, Kutas J (2017) A dióaknázó fényesmoly (Coptodisca lucifluella Clemens, 1860 Lepidoptera - Heliozelidae) magyarországi megjelenése. [The appearance of the walnut leafminer (Coptodisca lucifluella Clemens, 1860 Lepidoptera - Heliozelidae) in Hungary.] Növényvédelem 78(53): 539-541. [in Hungarian]

Tamura K, Nei M (1993) Estimation of the number of nucleotide substitutions in the control region of mitochondrial DNA in humans and chimpanzees. Molecular Biology and Evolution 10: 512-526.

Tuba K, Horváth B, Lakatos F (2012) Inváziós rovarok fás növényeken. [Invasive insects on woody plants.] Nyugat - magyarországi Egyetem, Sopron, 120 pp. [in Hungarian]

Weiss JE (1918) Einfluss der Witterungsverhältnisse auf das Auftreten von Pflanzenkrankheiten und tierischen Schädlingen 1916 und 1917. [Influence of weather conditions on the occurrence of plant diseases and animal pests in 1916 and 1917.] Zeitschrift für Pflanzenkrankheiten 28: 201-210. [in German]

\section{Supplementary material 1}

Table S1. Nearctic walnut leafminers invade Europe: First Coptodisca lucifluella (Clemens. 1860) and now $C$. juglandiella (Chambers. 1874) (Lepidoptera: Heliozelidae)

Authors: Attila Takács, Csaba Szabóky, Balázs Tóth, Miklós Bozsó, János Kutas, Szilárd Molnár, Ignác Richter

Data type: Table.

Copyright notice: This dataset is made available under the Open Database License (http://opendatacommons.org/licenses/odbl/1.0/). The Open Database License (ODbL) is a license agreement intended to allow users to freely share, modify, and use this Dataset while maintaining this same freedom for others, provided that the original source and author(s) are credited.

Link: https://doi.org/10.3897/nl.43.38686.suppl1 